\title{
Prisoner Regimes and a Transnational History from Below
}

\author{
Margaret Hunt \\ Department of History, Uppsala University, Uppsala, Sweden \\ Email: margaret.hunt@hist.uu.se
}

The society of prisoners: Anglo-French wars and incarceration in the eighteenth century. By Renaud Morieux. Oxford: Oxford University Press, 2019. Pp. viii + 421. ISBN 9780198723585.

Enemy combatants captured in wartime are both a potential resource for their captors and a logistical and security nightmare. This has long been reflected in their treatment. Over the centuries, captured enemy combatants have been sold as slaves (or simply used as slave labour), forced to switch sides, ransomed for money, swapped for other prisoners, physically maimed to ensure they could no longer fight, starved to death, imprisoned under abysmal conditions, or outright massacred. And yet, surprisingly, at other times (including in the period covered by this book), most prisoners of war-though not, as Morieux shows, all - have not only had a protected status but, especially in the case of officers, been allowed a degree of freedom of movement that seems extraordinary by modern-day standards.

The society of prisoners looks comparatively at policies 'on the ground' with respect to prisoners of war in France and Britain, two of the strongest and most centralized states of eighteenth-century Europe. One of the questions at issue is whether, as much of the literature on prisoners of war suggests, developed nation-states supported recognizably modern prisoner regimes. The time-period is significant here, not just because it coincided with the rise of what many historians like to call the fiscal-military state, but because it also saw a flowering of publishing and activism around human rights, including condemnations of torture, capital punishment, the slave trade, religious persecution, and the imprisonment of non-criminals. However, Morieux's book offers only limited support to attempts to connect either the centralizing state or Enlightenment ideas to more modern understandings of prisoners of war. Where these tendencies intersect it is often in unexpected and paradoxical ways, and the main thrust of the book is to demonstrate the

(C) The Author(s), 2021. Published by Cambridge University Press. This is an Open Access article, distributed under the terms of the Creative Commons Attribution licence (http://creativecommons.org/licenses/by/4.0), which permits unrestricted re-use, distribution and reproduction, provided the original article is properly cited. 
many ways in which prisoner regimes in both countries were far from 'modern'.

Thus, some of the most interesting and original sections in the book deal with the commodification of human beings in the prisoner-of-war regimes of the eighteenth century. As Morieux shows, this arose in large part from the highly entrepreneurial way that commerce raiding, imprisonment for debt, and, of course, the slave trade functioned in the eighteenth century. Ships captured by privateers, especially in European waters, could sometimes pay (or promise) a ransom in return for being allowed to continue on their journey; however, they usually had to leave hostages behind as security for its payment. Frequently, these hostages spent years as prisoners; moreover, because they were 'private' prisoners they did not necessarily go free when hostilities ended. Across the Caribbean, prisoner exchanges were used as a pretext to carry on private trade between warring islands and prisoners were bought, sold, and 'hired out' expressly for this purpose. Moreover, both in the Caribbean and elsewhere it was common to treat captured black soldiers and sailors as booty, to be sold as slaves, rather than as prisoners of war. Clearly the notion of the prisoner of war as a resource to be exploited for gain was alive and well in the eighteenth century, and often in tension with emerging notions of prisoners of war as a protected group.

These tensions or contradictions have implications for how we understand both war and early modern state formation. A number of scholars have recently argued for the importance of private entrepreneurship for early modern warfare and this has even given rise to a new phrase, 'the contractor state'. The society of prisoners offers support to this tendency, while at the same time it shifts the emphasis. Much of the 'contractor state' scholarship centres on entrepreneurs, and while this book certainly does not ignore such people, it prefers to emphasize much humbler folk-sailors, fishermen, persons of colour, prisoners of various kinds - who, often to their sorrow, fell victim to the appetite for private gain that was an essential element of the contractor state.

Of course, all of this looks very different from later prisoner-of-war accords like the Hague conventions of 1899 and 1907. Still, as Morieux shows, while the eighteenth-century system was in no way 'modern', it was a system, governed by recognizable rules. While private gain undoubtedly played a big role, there were always competing considerations. One of these was the notion of parity or reciprocity between nations when it came to the treatment of prisoners of war. Policies with respect to prisoners of war were always partly driven by fear that the enemy would exact reprisals on one's countrymen if their own people were poorly treated. However, this principle has not been much examined in practice, at least for the eighteenth century. One contribution of Morieux's book is to show the way the reciprocity principle permeated the entire prisoner-of-war regime, from the treatment of elite prisoners on parole, to prisoner exchanges, to ways of dealing with the victims of shipwrecks, to the above-mentioned issue of whether captured black soldiers and sailors were treated as prisoners of war or sold as slaves. 
A working system of reciprocity with respect to the treatment of prisoners requires relatively trustworthy information about what the other side is doing, and reliable intelligence is hard to come by in wartime. This gives rise to another important theme of the book, namely national, international, and transnational communication and information flows. How did states and other interested parties find out how the enemy was treating their men? What and who were the conduits through which this kind of news travelled? What was the role of rumour and 'fake news', of which Morieux gives several examples? What is clear is that it was through these usually informal negotiations and exchanges of information, between the Sick and Hurt Board of the Royal Navy (which also handled prisoners of war) and their French counterparts; between functionaries within countries; between prisoners and their captors (and later prisoners and prison guards); between the colonies and their metropoles; and many other combinations of people, places, and institutions that prisoner-of-war regimes came into being.

This is a more densely peopled account of the interplay between governments and the governed - both those of one's own and of other nations than we are accustomed to seeing for the early modern period; in fact, the book could be said to model a sort of transnational history from below, and it certainly features an unusually diverse and voluble cast of characters. This is not to say that everyone is there who could be there. While Morieux provides ample coverage of the prisoners themselves, and of the people who had to deal with them most directly, including revealing snapshots of the social tensions in some of the towns in which prisons and prisoners on parole could be found, he tells us much less about the communities from which most of these prisoners of war came, or about the role of those communities in these multivocal, transnational communication networks. In fact, the 'people left at home', wives, mothers, sisters of prisoners of war, but also older men, retailers, and local creditors of all kinds, also pushed their way into these complicated negotiations and tried to influence their outcome.

A telling example of what I am talking about comes from the later seventeenth century, a little before Morieux's book begins. In 1666, in the midst of the Second Anglo Dutch War, Samuel Pepys, then secretary of the Navy Board, wrote in his diary about the daily demonstrations by the wives and mothers of prisoners of war in and around the Navy Office in London. These women, at least three hundred strong, according to Pepys, were protesting the Navy's failure to pay monies owed both to them and to their husbands and other relatives imprisoned in Holland. Pepys had to pass these women on his way to the Navy Office, and he describes being 'tormented' by their cries, which included 'laying down the conditions of their families and their husbands, and what they have done and suffered for the King, and how ill they are used by us, and how well the Dutch prisoners of war are used here in England by the allowance of their masters'. These women were invoking

\footnotetext{
${ }^{1}$ This episode is discussed in more detail in Margaret R. Hunt, "Women and the fiscal-imperial state in the late seventeenth and early eighteenth centuries', in Kathleen Wilson, ed., A new imperial history: culture, identity and modernity in Britain and the Empire, 1660-1840 (New York, NY, 2004), pp. 29-47.
} 
the same logic of reciprocity used by governments, though to reinforce a somewhat different set of demands. This episode suggests strongly that sailors' kin had their own transnational communications networks, perhaps at least in part clandestine, through which information about the well-being of their imprisoned relatives came. It also offers a rather different picture of sailors' wives and families than we are accustomed to. These women were not sitting at home waiting for their menfolk to return; instead, they were loudly inserting themselves into a transnational conversation about the responsibility of states both to their own soldiers and sailors (and those men's families) and to imprisoned enemy combatants.

While Morieux's model of transnational communication arguably still has room to expand and diversify, that does not gainsay the importance of this work. The society of prisoners suggests many new ways to think about war, early modern states, modes of governance, communication, and transnational resistance in the pre-modern period. At its best it also models a new kind of history, a more complex and egalitarian notion of historical causality, and, finally, a real transnational history from below.

Cite this article: Hunt M (2022). Prisoner Regimes and a Transnational History from Below. The Historical Journal 65, 533-536. https://doi.org/10.1017/S0018246X21000431 